\title{
ICT and Teachers' Attitude in English Language Teaching
}

\author{
Gopala Krishnan Sekharan Nair ${ }^{1}$, Rozlan Abdul Rahim ${ }^{1}$, Roszainora Setia ${ }^{1}$, Aileen Farida binti Mohd Adam ${ }^{1}$, \\ Norhayati Husin ${ }^{1}$, Elangkeeran Sabapathy ${ }^{1}$, Razita Mohamad ${ }^{1}$, Shahidatul Maslina Mat So'od ${ }^{1}$, Nurul Izatee Md \\ Yusoff ${ }^{1}$, Razifa Mohd Razlan ${ }^{1}$, Nur Amalia Abd Jalil ${ }^{1}$, Elina Faradilla Nurul Huda@ Ariffin ${ }^{2}$ \& Norhafiza Abu \\ Seman $^{3}$ \\ ${ }^{1}$ Academy of Language Studies, Universiti Teknologi MARA (UiTM), Dungun Campus, Dungun, Malaysia \\ ${ }^{2}$ SK Pujut Corner, Pujut 1, Miri, Malaysia \\ ${ }^{3}$ Faculty of Administrative Science and Policy Studies, Universiti Teknologi MARA (UiTM), Dungun Campus, \\ Dungun, Terengganu, Malaysia
}

Correspondence: Gopala Krishnan Sekharan Nair, Academy of Language Studies, Universiti Teknologi MARA (UiTM), Dungun Campus, 23000 Dungun, Terengganu, Malaysia. Tel: 60-9-8400-8225/60-12-900-2602. E-mail: gopa1792@tganu.uitm.edu.my

Received: January 2, 2012 Accepted: February 27, 2012 Online Published: August 17, 2012

doi:10.5539/ass.v8n11p8 URL: http://dx.doi.org/10.5539/ass.v8n11p8

\begin{abstract}
The waves of globalization and the advent of IT have given some impacts to the teaching of English in Malaysia. ICT equipment has been integrated in English classes since it has been proven to help the students in their learning process. This study seeks to find out whether the teachers are in fact ready for this newer innovation. It checks on the teachers' attitude towards the use of ICT in English language teaching and the extent to which teachers use the available ICT equipment. A survey was conducted at 8 primary schools in Miri, Sarawak. A total of 60 teachers of English were selected and given a set of questionnaire. It was found that teachers have a satisfactory attitude towards the use of ICT and the teacher's level of ICT use is also satisfactory. Furthermore, a significant relationship was found when the attitude towards ICT was investigated with three different variables, which are the actual level of its use, the teachers' age and the experience in attending ICT workshop. It is hoped that more future research should be carried out in a wider sampling so that the findings can be generalized.
\end{abstract}

Keywords: extensive reading, teaching literature, perceptions, proficiency, syllabus

\section{Introduction}

English has moved from being an international language to a global language. Jayasankaran (1998), stated that English language no more belongs to England as it pervades all aspects of human activity especially in the field of Information Technology (IT).

Globalization and the advent of IT have placed English to a very important position in Malaysian education. Being an ex-colony of Britain has deprived Malaysia, than Malaya, in many ways. Colonization meant that at least a certain limited portion of the population became English speaking. Eventually the Ministry of Education of Malaysia replaced English with the Malay language as the language of instruction in schools in 1980 where every school in the country from standard one to form five, used Malay language as the medium of instruction. The change was indeed necessary as any sovereign nation would want to use its indigenous language and mother tongue as the language of learning.

However this change resulted in a steady decline in the standard of the English language in the country. In 2000, the Education Ministry took the initiative to introduce English literature component and new teaching methods using ICT in classroom to cater the problem. This included using ICT in English language teaching. Due to the undeniable important role that English

has in Malaysian education, this study primarily focuses on whether the teachers' attitude towards ICT would have a bearing on their actual level of use in the classroom. This study was carried out using a sample of 60 English teachers from eight primary schools around Miri Sarawak. There may be various factors, inherent in 
the population which may moderate the scores obtained; however it is beyond the scope of this research to take into account all those factors which may comprise the external variables. This may require a more comprehensive research which needs a longer time and a substantial budget.

\section{Literature Review}

\subsection{Use of ICT in English Language Teaching}

Alessi and Trollip (2001), contended that a lot of research findings indicate that using computers to teach is better than using books, teachers, films or other more traditional methods. Chan et al. (2007), stresses that the success or failure of the use of ICT in a classroom very much depends on the implementers. These implanters refer to the institution administrations as well as the teacher. Chan et al. (2007), also recommends that administrative support should take the form of practical allocations in terms of infrastructure, hardware, software and networking required to conduct IT classes.

\subsection{Attitude towards ICT}

Teachers have to be properly exposed towards ICT in becoming confident and willing users of the technology. Albion and Ertmer (2002), suggested that the duration of exposure of teachers to ICT is crucial in alleviating the skills and anxiety level. They argued that short term exposure to technology would be inadequate in equipping teachers with the necessary skills and knowledge for confident and masterful use of ICT in the classroom. Educational Planners should take heed of their findings. Brown and Warschauer (2006), echoed the views of Albion and Ertmer (2002), when they found that teachers performed better in using ICT when they were well grounded in the technology through workshops and training sessions that are of substantial duration.

\subsection{Value of ICT in Education and Teacher Readiness}

Davis (1989), clearly indicates that attitude may influence the level of use of ICT. Funds amounting to millions would be wasted expenditure if the classroom practitioners do not make optimal use of the resources available. Kent and Facer (2004), stressed that teachers must be properly trained and should be keen on using technology in the classroom. Barnett (1994), found that technology in the classroom does enhance learning if properly employed. He pointed out that teachers who started out their careers in an era when technology was not available would be difficult to convert to become users of modern technology. This group, according to him, must first be convinced of the merits of ICT in education before they use it in the classroom. Barnett (1994), stated that by no means must these teachers be coerced into using technology; they must first be developed into willing users.

\section{Methodology}

\subsection{Research Design}

A survey was conducted in 8 primary schools in Miri to gather the necessary data in examining all the research issues.

\subsection{Instrumentation}

A self-developed, pilot tested questionnaire was constructed to gather the relevant data.

The questionnaire consists of three (3) sections for obtaining data needed to answer different research questions.

\subsection{Samples}

60 school teachers which involved 39 females and 21 males, were selected from 8 primary schools in Miri, Sarawak and the teachers were those involved in the teaching of English. The stratified sampling method was used so that there was adequate representation from urban, suburban and rural localities.

\subsection{Data Collection and Analysis Method}

The questionnaire was distributed to all the samples involved. Since the respondents were regarded as adult and qualified respondents, no explanation, translation or guidance was given prior to answering all the questions. The questionnaire was analyzed using SPSS in determining the frequency distributions, descriptive statistics, correlation analysis and t-tests.

\section{Results and Discussions}

Descriptive statistics was used to answer Research Questions 1 and 2. On the other hand, inferential statistics in the form of Correlation Analysis was used to answer Research Questions 3 and 4. Research Questions 5 and 6 were answered using the t-test. 
Table 1. Teachers' attitude towards using ICT in English language teaching

\begin{tabular}{llll}
\hline Mean & Maximum possible mean & Mid-point Mean & Median \\
\hline 57.2 & 75 & 45 & 56.5 \\
\hline
\end{tabular}

4.1 Do Teachers Have a Satisfactory Attitude towards the Use of ICT In the Teaching of English?

Based on the results in Table 1, the mean score of the samples for attitude towards using ICT in English language teaching is 57.2 and since it is higher than the median (56.5), the attitude is considered satisfactory. However, this result has given a "wakeup call" for the teachers and the administrators as the sample mean of 57.2 is only slightly above the median of 56.5. Therefore, efforts need to be taken to ensure that teachers of English could have a self-satisfaction with the use of ICT in their teaching. The efforts should be taken by all parties involved in teaching and learning. Klein and Sorra (1996), suggested that the commitment of the users towards the use of a new system would depend on the attitude. If the problem of attitude is not addressed, it is worried that it can hinder teachers to be committed users of ICT.

\subsection{Is the Teachers' Level of ICT Use in the Teaching of English Satisfactory?}

Table 2 shows the score for the level of ICT use in the English language classroom. The mean obtained by the sample is 38.4. The median for the sample is 37.5 . Since, the sample mean is higher than the median, it can be concluded that the level of use is satisfactory.

Table 2. Teachers' level of ICT Use in English language teaching

\begin{tabular}{llll}
\hline Mean & Maximum possible mean & Mid-point Mean & Median \\
\hline 38.4 & 50 & 30 & 37.5 \\
\hline
\end{tabular}

The value obtained shows that teachers are using ICT in the classrooms. This is a very good sign, but all parties should not be complacent with the current situation. More improvements need to be taken into consideration to improve on the level of ICT use. Kay \& Knaack (2005), emphasized that attitude is critical to the integration of technology into teaching. Thus, if teachers are IT savvy, the use of ICT in English class will be more frequent.

\subsection{Is There a Significant Relationship between Attitude towards ICT and the Actual Level of Its Use?}

Based on the findings from Table 3, it was found that there is a strong positive correlation between attitude towards ICT and the level of its use.

Table 3. Relationship between attitude towards ICT and the level of use

\begin{tabular}{lll}
\hline Attitudes towards ICT use & Pearson Correlation Sig. (1-tailed) & 1 \\
& $\mathrm{~N}$ & 60 \\
\hline Level of ICT use & Pearson Correlation Sig. (1-tailed) & $0.638^{* * *}$ \\
& & 0.00 \\
$\mathrm{~N}$ & 60 \\
\hline
\end{tabular}

The Pearson ' $r$ ' value obtained is .638, indicating a strong positive relationship between attitude towards ICT use and the actual level of use. Clearly, the level of ICT use is higher when the attitude towards the use of ICT is more positive. This finding supports the findings done by Kay \& Knaack (2005), Klein and Sorra (1996).

Hence, it is a wise step if teachers' attitude towards ICT is nurtured. To do so, it is necessary not only to provide adequate facilities but also training and workshops for the teachers involved. Melone (1990), suggested that teachers should be properly exposed towards ICT to become confident and willing users of the technology.

\subsection{Is There a Significant Relationship between the Teachers'Age and Their Attitude towards the Use of ICT?}

The implication of this finding is that the administrators may have to consider more IT workshops for the older generation. The negative correlation between age and attitude certainly shows that increasing age would mean a lower attitude score. It is vital that the attitude of the older teachers be improvised. Better attitude leads to more use of ICT. 
Table 4. Relationship between age and attitude towards ICT

\begin{tabular}{lll}
\hline Attitudes towards ICT use & Pearson Correlation Sig. (1-tailed) & 1 \\
& $\mathrm{~N}$ & 60 \\
\hline Age & Pearson Correlation Sig. (1-tailed) & $-.614^{* * *}$ \\
& & 0.00 \\
& $\mathrm{~N}$ & 60 \\
\hline
\end{tabular}

The age of teachers is something that cannot be changed but their attitude level may be raised by suitable and frequent workshops. Education Administrators must recognize that the older generation may face stress in the face of new technology. Once this recognition is there, the authorities should attempt to give more training, starting from the very basic to the older generation.

4.5 Is There a Significant Difference in Attitude towards the Use of ICT between the Younger Teachers (20-30 Years) and the Older Teachers (41-50 Years)?

Table 5 shows the existence of a significant difference between the attitude score of teachers aged between 20-30 and those aged between 41-50 years old. The 20-30 year old group has a higher attitude score, with the mean of 62.92 .

Table 5. Means of attitude scores of age groups

\begin{tabular}{cccc}
\hline Age(years) & $\mathbf{N}$ & Mean & Std. Deviation \\
\hline $20-30$ & 15 & 62.92 & 11.59 \\
$41-50$ & 11 & 51.82 & 2.32
\end{tabular}

Since the difference between the older and the younger generation is significant, it calls for concrete steps to be taken to address the problem. Educational Administrators should not ignore the difference that exists and should take pains to see that there is more focus on the older generation in terms of training and workshops. They should also think of different kinds of workshop and training for the younger and older teachers. If possible special workshops should be held for the older generation as they differ significantly from the younger generation in their attitude towards ICT.

4.6 Is There a Significant Difference between Those Who Have Attended ICT Workshops and Those Who Have Not in Their Attitude towards the Use of ICT?

Table 6 shows that there exists a significant difference between the attitude score of those who have attended ICT workshops and those who have yet to undergo any ICT training. The t-Test shows that there is a significant difference between the attitude score of these two groups. This finding indicates that the workshops are indeed useful. However the workshops must be more regular and the workshop learning content must be different for the younger and older age group.

Table 6. Means of attitude score of those who have attended ICT workshops and those who have not

\begin{tabular}{cccc}
\hline Attended ICT workshops & N & Mean & Std. Deviation \\
\hline No & 39 & 54.2 & 11.59 \\
Yes & 21 & 62.7 & 2.32 \\
\hline
\end{tabular}

\subsection{Implications of the Study}

This study gives hope to Policy Planners and Ministerial Officers in improving and adding (or deleting) current policies in regards to the teaching of English. It also indicated areas which needed more attention.

It is heartening to note that the attitude level towards ICT and the level of actual use are satisfactory. However, the score for attitude and level of use is just marginally above the median. Ideally a much higher score should be obtained.

This study also provides hope for workshops to produce results as there appears to be a significant difference between those who have attended workshops and those who have not. The implications are that more workshops should be held and the Educational Authorities should ensure that many teachers are given the opportunity to attend the workshops.

The other implication is that this study should have created awareness that the older generation need more attention when it comes to getting familiar with new systems like ICT in Education. Clearly the older generation 
does not take to ICT as easily as the younger generation. In light of this the Education Planners should ensure that the older generation gets more training.

In addition, this study also carries the implication that in order to enhance the use of ICT in the classroom one must tackle the problem at the source. It is the teachers' attitude that determines their level of use of ICT in the classroom. As such the teachers' attitude problems should be addressed if the Ministry hopes to solve the problem of lack of ICT use in the classrooms. During workshops teachers must be convinced of the usefulness of ICT so that they will become willing rather than compliant users of the system. Melone (1990), points out that when a person is merely using a system because he is required to do so, the benefits will be diminished and will not be in the best interest of all concerned. Thus workshops should not only concentrate on imparting skills but also make efforts to convince the teachers of the merits of using ICT in the classroom.

\section{Conclusion}

First of all, the authorities need to take Action needed that is frequent, regular and comprehensive. For example, workshops are not only to train teachers on ICT skills but also to convince them of the usefulness of using ICT in the classroom. The authorities should also have awareness that the needs of the older teachers are different from those of the younger ones and hence, any effective workshops should be customized to the needs of these two generations.

This study also generates ideas for new research. This study investigates whether attitude has a bearing on level of use. However, according to Frishbein and Ajzen (1975), attitude may be shaped by various behavior and evaluation of ICT. Future researchers should investigate the relationship between beliefs and evaluations and attitude. This would generate a lot of useful information to the Education Planners on how attitude may be shaped.

While there is clear empirical evidence that attitude can affect actual level of use, there are a lot of factors such as culture, geographical location and presence of adequate facilities which may act as a moderator between attitude and actual level of use of ICT. Future research on these moderators needs to be done so that their impact on the level of use can be determined. The findings would certainly be helpful for the administrators to strategize ways of minimizing the ill effects of such moderators.

Much has been said in Literature Review about the usefulness of ICT in teaching English. More research needs to be done to investigate the actual usefulness of ICT in Malaysian classrooms. There should also be experimental research to find out whether ICT enhanced lessons are more effective than conventional lessons.

\section{References}

Albion, P. R., \& Ertmer, P. A. (2002). Beyond the foundations: The role of vision and belief in teachers' preparation for integration of technology. Tech-Trends, 46(5), 34-38. http://dx.doi.org/10.1007/BF02818306

Alessi, S. M., \& Trollip, S. R. (2001). Multimedia for Learning (3rd ed.). USA: Allyn andn Bacon.

Barnett, R. (1994). The Limits of Competence: Knowledge, Higher Education and Society. Open University Press, Buckingham.

Brown, D., \& Warschauer, M. (2006). From the university to the Elementary classroom: Students' experiences in learning to integrate technology in instruction. Journal of Technology and Teacher Education, 14(3), 599-621.

Chan et al. (2007). Computer Education for Classroom Teaching. Malaysia: McGraw-Hill.

Davis, F. D. (1989). Perceived usefulness, perceived ease of use and user acceptance of information technology. MIS Quarterly, 13(3), 319-339. http://dx.doi.org/10.2307/249008

Frishbein, M., \& Ajzen, I. (1975). Belief, Attitude, Intention and Behavior: An Introduction to Theory and Research. Reading, MA: Addison-Wesley.

Jayasankaran, S. (1998, December 10). The Multinationals and Language: Far Eastern Economic Review.

Kay, R. H., \& Knaack, L. (2005). A case for ubiquitous, integrated computing in teacher Education. Technology, Pedagogy and Education, 14(3), 391-412. http://dx.doi.org/10.1080/14759390500200213

Kent N., \& Facer K. (2004). Different worlds? A comparison of young people's Home and school ICT use. Journal of Computer Assisted Learning, 20, 440-455. http://dx.doi.org/10.1111/j.1365-2729.2004.00102.x

Klein, K. J., \& Sorra, J. S. (1996). The Challenge of Innovation Implementation. Academy of Management Journal, $21,1055-1080$.

Klein, K. J., \& Sorra, J. S. (1996). The Challenge of Innovation Implementation. Academy of Management Journal, 21, 1055-1080.

Melone, N. P. (1990). A Theoretical Assessment of the User Satisfaction Construct in Information Systems Research. Management Science Journal, 36, 76-91. http://dx.doi.org/10.1287/mnsc.36.1.76 